\title{
Ontferming "beyond" vergeving als weg naar heling en heelheid: "Reframing" als narratief-pastorale bemachtiging
}

\author{
Tiny van der Schaaf en Yolanda Dreyer ${ }^{1}$ \\ Departement Praktiese Teologie \\ Universiteit van Pretoria
}

\begin{abstract}
Mercy beyond forgiveness as a way to healing and wholeness: Reframing as narrative pastoral empowerment

The theme of this article is pastoral counselling with women who have been sexually violated in an ecclesial context. The article focuses on the exegesis of those passages on guilt and forgiveness in the Gospel of Matthew frequently used by theologians and pastors in this regard. The article points to the implications for counselling. The aim is to empower women who have been violated and who struggle with the Christian imperative to forgive. Donald Capps' notion of "reframing" with regard to "first order" and "second order" change is complemented by the narrative philosophy of Paul Ricoeur on prefiguartion, configuration and refiguartion. The article is concluded by indicating a possibility for the abused woman to be liberated from the lingering power of the abuser. There is no direct link between them any longer. To become whole is the acceptance of forgiveness and to empower others to heal.
\end{abstract}

\section{INLEIDING}

In een voorgaand artikel $^{2}$ hebben wij het doel van het onderzoek geformuleerd als "om een handvat te creëren voor pastoraat met vrouwen die

\footnotetext{
${ }^{1}$ Tiny van der Schaaf, theologiestudent aan de Vrije Universiteit, Amsterdam heeft onderzoek voor dit artikel gedaan aan de Universiteit van Pretoria in 2004 onder de leiding van Prof dr Yolanda Dreyer.

${ }^{2}$ Van der Schaaf, T \& Dreyer, Y 2004. Ontferming "beyond" vergeving als weg tot heling en heelheid: Een theoretisch model voor narratief pastoraat.
} 


\section{Ontferming "beyond" vergeving als weg naar heling en heelheid}

slachtoffer zijn gemaakt van seksueel geweld binnen de kerkelijke gemeenschap en die worstelen met het begrip vergeving". In het eerste artikel is Christie Neuger's model voor pastoraat met vrouwen aangevuld met de narratieve filosofie van Paul Ricoeur. In dit tweede artikel word een bijbelstheologisch model vanuit het Mattheüsevangelie beschreven. Daarin worden de begrippen schuld en vergeving belicht. De reden dat voor het Mattheüsevangelie is gekozen, is dat Mattheüs de eis om te vergeven als een imperatief van Jezus stelt (zie het Onze Vader gebed in Mt 6:12). Jezus legt volgens Matteüs met de gelijkenis van de koning en de schuldeiser aan Petrus uit dat vergeving onvoorwaardelijk gegeven moet worden, zeventig maal zeven. Dit perspectief op goddelijke vergeving geeft voor veel vrouwen die tot slachtoffer zijn gemaakt, problemen. Om deze problemen te overstijgen wordt het pastorale model van "reframing" van Donald Capps toegevoegd tot het theoretische model voor narratief pastoraat van Neuger.

Teologische denkbeelden over zonde, oordeel en vergeving en wat voor invloed deze denkbeelden hebben op het bedrijven van pastoraat worden beschreven aan de hand van het 1991 werk van T W Buckley, Seventy Times Seven, Sin, Judgement, and Forgiveness in Matthew. Tot slot wordt er gezocht naar een alternatief voor deze denkbeelden.

\section{VERGEVING EN OORDEEL IN MATTHEÜS}

Een rode draad die volgens Buckley (1991:16) door het evangelie van Mattheüs loopt is vergeving. Dit moet niet gezien worden als het hoofdthema, maar als iets wat overal in verweven is. Het begin van deze rode draad is de kruisdood van Jezus. Door zijn dood aan het kruis bevrijdt Jezus mensen van hun zonden. De mensen die zich in geloof naar Jezus toekeren, worden vergeven. Wanneer deze goddelijke vergeving het hart van de mens raakt, stelt het de mens in staat om anderen te vergeven (Buckley 1991:12). Dat de vergeving van zonden door de kruisdood van Jezus een belangrijk punt is voor Buckley (1991:17, 19, 21, 39 56, 57-60, 66-68, 78, 88-99) blijkt uit het feit dat hij dit meerdere malen noemt.

Vergeving van zonden is een goddelijk voorrecht. Doordat Jezus mens en God is, kan Hij zonden vergeven (Buckley 1991:60). Deze autoriteit heeft hij gekregen bij de theofanie na zijn doop in de Jordaan (Mt 3:13-17). Deze theofanie heeft gezorgd voor de goddelijke inhoud van wat Jezus heeft gedaan. God is daarin aanwezig. Door de uitstorting van de Geest en de stem uit de hemel wordt Jezus gehoorzaam om het leven te leven wat God van Hem vraagt. De theofanie is de erkenning van Jezus als Zoon van God (Buckley 1991:67). Alles wat Jezus doet is een vervulling van wat de profeten 
hebben voorspeld (Mt 1:22; 2:17; 4:14; 5:17). Jezus heeft ervoor gezorgd dat het nieuwe verbond (Jer 31:31-34) tussen God en mensen tot stand kon komen. In het licht van dit nieuwe verbond moeten mensen klaar zijn om elkaar te vergeven. Dit is een voorwaarde voor de goddelijke vergeving. Gelijk God ons vergeeft, moeten wij anderen vergeven (Mt 6:12, 14-15). Een verduidelijking van deze voorwaarde wordt gegeven in Matteüs 18:21-35 waar Jezus een gelijkenis vertelt over vergeving. De koning in het verhaal vergeeft een slaaf, maar die slaaf vergeeft op zijn beurt niet een andere slaaf die hem iets schuldig is. Wanneer de koning dit hoort trekt hij zijn genade terug van de eerste slaaf en geeft hem in handen van de folteraars. Jezus sluit de gelijkenis af met "Alzo zal ook mijn hemelse Vader u doen, indien gij niet, een ieder zijn broeder, van harte vergeeft" (Mt 18:35). Het is de bedoeling dat het meelijden en de vergeving van de Hemelse Vader weerspiegeld wordt in de relatie van Gods kinderen onderling (Buckley 1991:14). Mensen kunnen elkaar vergeven omdat God hun zonden vergeeft doordat Jezus voor hen gestorven is aan het kruis (Buckley 1991:21). Jezus is de middelaar. Door het vergieten van zijn bloed is er een nieuw verbond ontstaan, waardoor is vergeving mogelijkis geworden. Jezus is onze redder. Als Zoon van God is Hij de belichaming van de goddelijke genade. Dit alles wordt door Buckley (1991:94-95) als volgt samengevat: "Jesus' own death reveals the truth: that God is pleased to receive the blood of his true servant and Son to requite the blood shed since the fall of man, to forgive us our sins, and through our redemption from sin, guilt, and estrangement, to reveal anew the love he revealed at creation."

De uitleg die Buckley van het evangelie van Mattheüs geeft, is sterk apocalyptisch. Alles wat Jezus doet en zegt is gericht op het koninkrijk van God. Daar zijn alle zonden vergeven. De vraag is echter hoe een mens toegang krijgt tot dit koninkrijk. Hier wordt het vervolg van de rode draad zichtbaar. Volgens Buckley wordt er over ieder mens een oordeel geveld. In dit laatste oordeel wordt alles wat mensen hebben gezegd of gedaan, gewogen. Mattheüs schrijft gedetailleerd over het laatste oordeel (Buckley 1991:39). Wanneer het laatste oordeel geveld wordt zijn er slechts twee mogelijkheden: eeuwig leven of eeuwige straf. Het oordeel wat over iemand geveld wordt is afhankelijk van het feit hoe iemand het gebod van de liefde heeft beantwoord (Buckley 1991:94). Daar zit in besloten of iemand zijn of haar naaste heeft vergeven.

Om zijn verhaal te onderstrepen legt Buckley in zijn boekje gelijkenissen uit over de komst van het einde der tijden. Een voorbeeld hiervan is zijn uitleg van de gelijkenis van de talenten (Mt 25:14-30). Mensen 


\section{Ontferming "beyond" vergeving als weg naar heling en heelheid}

moeten hun talenten ${ }^{3}$ benutten. Wanneer dit niet gedaan wordt, zal het oordeel volgen, net als bij de slaaf die zijn ene talent heeft begraven om het vervolgens terug te kunnen geven aan zijn heer. Er is geen excuus, geen reden om het talent niet te gebruiken (Buckley 1991:52-54).

Het laatste stuk van de rode draad gaat over de enige onvergeeflijke zonde die de mens kan begaan (Mt 12:31). Deze enige onvergeeflijke zonde is lastering van de Geest. Volgens Buckley (1991:26) impliceert lastering van de Geest een bewust tegenstaan van de genade en dat is onvergeeflijk. Die genade en vergeving zoals hierboven al duidelijk werd, heeft de mens echter nodig om medemensen te kunnen vergeven. Wanneer een mens een medemens niet kan vergeven, wordt hij of zij daarop afgerekend bij het laatste oordeel. Hiermee is de cirkel rond.

\section{CONSEQUENTIES}

De manier waarop Buckley het Mattheüsevangelie uitlegt is genadeloos voor vrouwen die slachtoffer zijn van seksueel geweld. Dit klinkt paradoxaal. De mens ontvangt toch de genade en vergeving van God door de kruisdood van Jezus. Hoever gaat echter die genade? In de vorige paragraaf is duidelijk geworden dat de goddelijke vergeving het hart van de mensen moet raken. Wat gebeurt er als dit niet het geval is? Uit het voorgaande artikel bleek namelijk dat veel slachtoffers niets meer met het geloof en God kunnen. Wanneer Buckley schrijft dat God alle zonden vergeeft door de kruisdood van Jezus dan heeft dit vergaande gevolgen. In de beleving van de dader betekent het vrijspraak. De dader wordt niet ter verantwoording geroepen. Voor het slachtoffer betekent het dat ze buiten spel komt te staan. Als God alle zonden vergeeft door de kruisdood van Jezus, is bekering van de dader en vergeving van het slachtoffer dan nog noodzakelijk? Daar komt nog bij dat de vrouw die tot slachtoffer gemaakt werd onder druk wordt gezet. Ze moet vergeven. Immers, een voorwaarde voor goddelijke vergeving is dat gelovigen hun medemens vergeven. De passage in het Onze Vader: "...vergeef ons onze schulden, gelijk ook wij vergeven onze schuldenaren;..." (Mt 6:12) is voor vele vrouwen die tot slachtoffer gemaakt zijn onmogelijk om te bidden.

\footnotetext{
${ }^{3}$ Buckley gaat hier met zijn exegese kort door de bocht. Hij gaat uit van de geestelijke betekenis van het woord "talent". In beginsel echter moet het woord economisch worden opgevat. Het gaat om geld. De gelijkenis beschrijft de realiteit van het dagelijkse leven; de rijken worden rijker en de armen worden armer. De derde slaaf heeft verstandig en betrouwbaar gehandeld, maar krijgt een onverwachte reactie van de meester. B B Scott trekt in zijn commentaar een lijn tussen het ene talent wat de derde slaaf onder zijn beheer gekregen heeft, en de Tora. De Tora is iets wat beschermd moet worden, een toevertrouwd pand, maar ook een last. Wanneer de Tora aan het einde van het leven ongeschonden wordt terug gegeven, is dat een reden tot vreugde. Israël is verantwoordelijk voor de Tora, net als die slaaf voor dat ene talent. Het naleven van de Tora leidt tot vervolging, maar als het volk trouw blijt is er een toekomst met Adonai. De gelijkenis van de talenten forceert de lezer om te kiezen voor een toekomst om in te leven. Wat Jezus hier vertelt is een vervolg van hetgeen Hij gezegd heeft in de Bergrede (Scott 1989:224-235).
} 
Het versterkt het gevoel dat ze tekort schieten ten opzichte van de medemens en van God. Daarnaast voelen ze zich verantwoordelijk voor hetgeen er gebeurd is. Daardoor wordt het schuldgevoel nog groter.

Het tweede aspect wat problemen oproept is Buckley's interpretatie van de wil van God. Het lijden en sterven van Jezus was de wil van God: "Uw wil geschiede" (Mt 6:10). God stelt het lijden van Gods kinderen op prijs. Dit heeft als gevolg dat vele vrouwen niets zeggen over hun misbruik, het is immers Gods wil (vgl Ganzevoort \& Veerman 1999:75-76). Nog scherper gezegd: Hoe kunnen slachtoffers om recht roepen tot een God die zelf gekozen heeft om groot onrecht te dragen (Ganzevoort \& Veerman 1999:88)? De kritiek van Emmanuel Levinas (in Duyndam \& Poorthuis 2003:124) op het christendom vat het bovenstaande goed samen:

\begin{abstract}
Het christendom zou vergeving als een magisch-sacramenteel gebeuren beschouwen, waarbij de eigen verantwoordelijkheid van de dader wordt miskend en het slachtoffer wordt genegeerd. (...) De christelijke opvatting van het sacrament van verzoening zou erop neerkomen dat voorafgaand berouw van de dader en herstel jegens het slachoffer geen noodzakelijke voorwaarden zijn voor vergeving van de kant van God.
\end{abstract}

Met een dergelijke uitleg van het evangelie wordt het slachtoffer opnieuw slachtoffer. Dat kan toch niet de bedoeling zijn van een "goede boodschap"? Voor "configuratie" en "refiguratie" (mimesis 2 en 3) (zie voorgaand artikel) is het noodzakelijk om de bijbelverhalen opnieuw te verstaan. Dit vraagt een kritische lezing van en "engagement" met de bijbelse verhalen.

\title{
4. CONFIGURATIEVE INTERPRETATIE
}

Het tegenstrijdige van Buckley is het beeld van een rechtvaardige (oordelende) God die onrecht toelaat. De uitleg die Buckley geeft verdoezelt onrecht. Volgens Ganzevoort \& Veerman (1999:78-79) is de soort interpretatie die Buckley geeft over het oordeel, te algemeen. Het gaat niet om de algemene zondigheid van de mens, het gaat om het concrete kwaad wat de ene mens de ander aandoet. Oordeel is partij kiezen voor de slachtoffers en de strijd aangaan tegen de machten van het kwaad.

Buckley haalt het Mattheüsevangelie uit de metanarratief van schuld en vergeving. In de context waarin het Mattheüsevangelie ontstaan is, wordt met betrekking tot deze metanarratief een hele andere visie zichtbaar. Daar wordt onrecht niet verdoezeld. Men kan het Mattheüsevangelie niet los zien van de context waar het in ontstaan is en waar het in thuis hoort. De schrijver van het evangelie kan niet los gezien worden van de tijd waarin hij leefde. Hij heeft 


\section{Ontferming "beyond" vergeving als weg naar heling en heelheid}

ook veel gebruik gemaakt van teksten uit wat we nu het Oude Testament noemen. Hij was deel van de theologie van zijn tijd. Friedrich Schleiermacher is van mening dat ieder woord alleen kan worden begrepen als een deel van het geheel, net als ieder hoofdstuk binnen een werk als geheel. Aan de andere kant kan het geheel pas begrepen worden vanuit het deel ( Van Aarde 2003:552). Jacques Derrida (1978:102-109) gaat verder en focust op de "verwijzende hermeneutiek" (différence) omdat teksten altijd in een meervoudige plurale werkelijkheid ingebed zijn. Dit vraagt om oog te hebben voor de holistische, literaire context van Mattheüs en de judaïstische culturele context van de eerste lezers van het evangelie.

Buckley scheidt in zijn het uitleg van Mattheüsevangelie, het evangelie van zijn context waar het onlosmakelijk mee verbonden is. Het afzonderlijke deel (het evangelie van Mattheüs) moet gekend worden van vanuit het geheel (de context), en andersom. In die context is God tegen onrecht (Lv 19:33-37; Ps 32; Ps 72; Jes 1:16-17; Jer 7:3-7). Er staat geschreven dat God onrechtvaardigen en goddelozen vernietigt en ten gronde richt. Er zijn dus grenzen aan vergeving, barmhartigheid en genade (Ganzevoort \& Veerman 1999:67). Jezus handelt in de lijn van de Tora en de profeten. Hij komt op voor de armen en verdrukten en Hij eet met tollenaars en zondaars (Mc 2:1617; Lc 5:27-32). Jezus veroordeelt niet zomaar (LC 7:36-50; Jh 8:2-11. Hij kijkt naar wat er in een mens leeft en niet naar uiterlijk vertoon (Mt 6:1-18; Mc 7:123). Onrecht wordt niet verdoezeld in wet, profeten en evangelie.

Wat verder verheldering nodig heeft is het begrip "koninkrijk" - een begrip wat Buckley vaak gebruikt. De manier waarop hij het woord koninkrijk gebruikt impliceert dat slachtoffers het onrecht in hun aardse leven moeten verdragen. Later in het koninkrijk van God zal alles beter zijn. Wat wordt nu eigenlijk verstaan onder het woord koninkrijk? Buckley schrijft over het koninkrijk als zijnde het hiernamaals, wat komt bij het einde der tijden, het laatste gericht. leder mens wordt aan dat gericht onderworpen. Het wordt duidelijk welke mens toegang heeft tot het koninkrijk en welke mens niet. Maar wat bedoelt Jezus wanneer hij spreekt over het koninkrijk? Is het koninkrijk inderdaad alleen maar het hiernamaals wat een mens slechts kan bereiken via het laatste gericht? Hoe moet het dan met mensen die nu verlangen naar het koninkrijk, mensen die slachtoffer zijn van onrecht, de arme, de verdrukte, de zieke, de bedelaar, de vreemdeling, een slachtoffer van seksueel geweld?

In Matteüs 4:17 begint Jezus met de verkondiging van het koninkrijk der hemelen. Dit roept tegenstrijdige reacties op. In de eerste plaats zijn daar de Farizeeën die niet begrijpen wat Jezus met het koninkrijk bedoelt. Dat blijkt uit hun reactie op het feit dat Jezus iemand geneest op sabbat en aren plukt 
op sabbat (Mt 12). De verkondiging van het koninkrijk is voor hen een mysterie. Jezus veroordeelt de Farizeeën om hun blindheid (Minear 1982:81). Daar tegenover staan de mensen die wel zien wat Jezus met het koninkrijk bedoelt en die bereid zijn om voor hem te sterven (Minear 1982:83). De verkondiging van het koninkrijk loopt als een rode draad door het Mattheüsevangelie. Het woord evangelie betekent voor de evangelist niets anders dan de verkondiging van dat koninkrijk (Mt 4:23-25; 9:35; 24:14). Het Mattheüsevangelie kan daarom niet gezien worden als een exclusief christologische georiënteerde verkondiging, zoals Buckley het doet (Luz 1985:173). Hij komt steeds weer terug bij de boodschap dat Jezus voor de zonden van de mensen is gestorven en dat daardoor vergeving mogelijk is geworden. Het evangelie blijft gerechtigheid benadrukken, gerechtigheid die de discipelen moeten doen aan de mensen en mensen aan elkaar.

In de Bergrede (Mt 5-7) legt Jezus uit hoe het er aan toe hoort te gaan in dat koninkrijk. Hij onderstreept deze verkondiging met zijn handelen en genezingen. Op die manier geeft Jezus gestalte aan het koninkrijk. Het koninkrijk is daar waar het woord van God (Tora en Profeten) wordt nageleefd. Het is daar waar het onrecht wordt bestreden en de zwakkeren worden beschermd. Jezus zegt dat Hij niet gekomen is om de wet en de profeten te ontbinden, maar juist om te vervullen (Mt 5:17). Bij Jezus heeft de praxis voorrang op de leer (Mt 7:15-23). Hij leeft de wet en de profeten. Deze interpretatie van het koninkrijk geeft ruimte voor slachtoffers om het onrecht wat hun is aangedaan onder de aandacht te brengen. Slachtoffers hebben het recht om gehoord te worden. Wat hen is aangedaan is tegen de wet en de profeten en tegen het evangelie van het koninkrijk dat Jezus verkondigt. Alleen met de erkenning van het onrecht kan heling plaatsvinden.

Het laatste punt van Buckley wat van belang is voor dit onderzoek en wat daarom geherinterpreteerd moet worden, is zijn uitleg van de bede: “... vergeef ons onze schulden, gelijk ook wij vergeven onze schuldenaren; ..." (Mt 6:12). Deze bede is voor vele slachtoffers moeilijk, dan wel niet onmogelijk, om te bidden vanwege de voorwaarde die gesteld wordt aan het verkrijgen van de goddelijke vergeving. Ook bij het interpreteren van deze perikoop is het belangrijk om de context niet uit het oog te verliezen.

Mattheüs maakt in deze bede gebruik van het woord "schuld". Dit in tegenstelling tot Lucas die in de eerste helft van de bede gebruik maakt van het woord zonde en pas in de tweede helft het woord schuld introduceert (LC 11:4). Mattheüs volgt het het joodse concept van schuld, dat wil zeggen materiële schuld. Het jodendom heeft op dit gebied een uitgebreide traditie. Hoe functioneert deze schuldvergeving in de joodse levenspraktijk? De realiteit is dat schulden (leningen) in het dagelijks leven niet vergeven worden. 


\section{Ontferming "beyond" vergeving als weg naar heling en heelheid}

Wanneer het gaat om liefdadigheid wordt er niets terug verwacht, maar in geval van een lening gaat de persoon die het geld leent ervan uit dat hij of zij het geld ook daadwerkelijk terugkrijgt. Onder welke omstandigheden zal een crediteur dan toch de schuld kwijtschelden en wordt dit beschouwd als een religieuze plicht? Het antwoord op deze vraag is te vinden in Deuteronomium 15:1-2 waar geschreven staat:

$\mathrm{Na}$ verloop van zeven jaar zult gij een kwijtschelding doen plaats hebben. En dit is de wijze van kwijtschelding: iedere schuldeiser zal hetgeen hij aan zijn naaste leende, kwijtschelden; hij zal zijn naaste en zijn broeder niet tot betaling dwingen, omdat men een kwijtschelding voor de HERE heeft afgekondigd.

In de vroege rabbijnse periode werd echter een nieuwe wet ingevoerd, de prosbul. Deze wet nam de mensen die het geld uitleenden in bescherming, want met het invoeren van deze wet was het toegestaan ook na het aanbreken van het zevende jaar de schuld terug te vorderen. In het licht van deze geschiedenis is het mogelijk dat de auteur van het Onze Vader deze wet verworpen heeft en als reactie daarop de bede in het Onze Vader geschreven heeft. Hij wil dat de wet die in de Tora staat weer tot uitvoering wordt gebracht (Lachs 1987:121-122). De vraag is of het woord schuld slechts materiëel mag worden opgevat. In de twee verzen (Mt 6:14-15) die direct na het Onze Vader volgen, heeft de schrijver van het evangelie het woord schuld vervangen door zonde. Lachs (1987:122-123) noemt het verschil wel maar gaat er verder niet op in.

Herman Waetjen (1999:85-86) beschrijft het gebruik van het woord schuld vanuit joods perspectief als volgt: voor het jodendom en de vroege Israëlitische religie werd schuld bepaald bij het deelnemen aan het verbond met Adonai. Het boek Deuteronomium geeft dit verbond duidelijk aan. Bij het houden aan de geboden leeft men in welvaart, maar bij het veronachtzamen van de geboden, gaat het mis (Dt 7:8, 11-15; 28:15-24). Wederkerigheid en verplichting karakteriseren dit verbond in het Oude Testament. God heeft het volk verlost uit Egypte en heeft met het volk een verbond gesloten en het gesticht als gezin van God. Als hoofd van het gezin maakt Adonai het volk moreel bewust door het zijn geboden op te leggen. Door te leven en te handelen volgens deze geboden is het volk verzekerd van een toekomst.

Daar tegenover stelt Waetjen het nieuwe gezin van God aan wie God autoriteit verleent door de opstanding van Jezus Christus. Dit nieuwe gezin wordt gekarakteriseerd door het vrij zijn van verplichtingen. Er is geen sprake meer van wederkerigheid. Het verbond met schuld is vervangen door een verbond van genade en vrijheid. Vergeving is nu ongelimiteerd. Op de vraag 
hoe vaak een mens zijn of haar naaste moet vergeven, is het antwoord oneindig, want de integriteit van Gods zonen en dochters vereist een ongelimiteerde kwijtschelding van alle schuld (Waetjen1999:87). De enige verplichting voor degene die zichzelf als een lid beschouwt van het gezin van God, is handelen en zijn zoals God. Jezus zegt in de Bergrede: "Gij dan zult volmaakt zijn, gelijk uw hemelse Vader volmaakt is" (Mt 5:48). Waetjen voert het consequent door, wanneer een mens de ander vergeeft, dan komt hij of zij in aanmerking voor de vergeving van God. Als mensen niet kunnen vergeven doen ze hun eigen integriteit geweld aan en negeren hun identiteit als lid van het gezin van God. Het resultaat is dat ze God's vergeving verspelen.

Deze manier van interpreteren van de bede over vergeving in het Onze Vader laat net als bij Buckley geen ruimte open voor slachtoffers. De reden hiervoor is dat "wij" en "ons" ongeïndentificeerd blijven. In het Mattheüsevangelie zijn een aantal lijnen zichtbaar. Het is belangrijk die te onderscheiden. Deze lijnen zijn de verhoudingen tussen de verschillende personen/groepen die in het Mattheüsevangelie een rol spelen. Het ene karakter bepaalt de rol van het andere karakter. De volgende verhoudingen die van belang zijn voor dit onderzoek zijn terug te vinden in het Mattheüsevangelie: Jezus/schare, Jezus/discipelen, Jezus/Joodse leiders, Joodse leiders/schare, Joodse leiders/discipelen, discipelen/schare.

De verhouding tussen Jezus en de discipelen wordt zichtbaar in de Bergrede. Jezus richt zich in de eerste plaats tot hen (Mt 5:1-2). Hij legt de discipels de spelregels van het koninkrijk uit. Ze moeten meer recht doen dan de Farizeeën (Mt 5:20). Hij geeft hen de macht om onreine geesten uit te drijven en mensen te genezen, en de opdracht om om te kijken naar de schare (Mt 10:1-8). De discipelen is het gegeven om de geheimenissen van het koninkrijk te zien. Zij horen en zien, dit is niet aan iedereen gegeven (Mt 13:10-17). Later in het evangelie schrijft Mattheüs dat de discipelen de sleutel van het koninkrijk krijgen (Mt 16:16-20). Hier wordt de verhouding zichtbaar tussen de discipelen en de schare. Dit blijkt ook uit de adressering van Jezus. De discipelen komen in achtien perikopen voor, terwijl de schare maar in zes perikopen voorkomt. De nadruk ligt op het onderricht van de discipelen (Minear 1982:87-88). De discipelen moeten gerechtigheid doen aan de schare, meer dan de Farizeeën. Het recht wat de Farizeeën doen aan de schare is slechts uiterlijk vertoon. De houding van liefde ontbreekt ten opzichte van de schare (Van Aarde 1994:42). De discipelen krijgen de opdracht om voor de schare te zorgen. Zij moeten de schare voeden.

De discipelen zijn heel geworden door Jezus, zij hebben liefde en vergeving ontvangen. Zij krijgen nu de opdracht om dit door te geven aan de schare. In deze context staat het Onze Vader. Jezus leert de discipelen dit 


\section{Ontferming "beyond" vergeving als weg naar heling en heelheid}

gebed. Aan hun is vergeving geschonken, zij zien. Hun opdracht is nu om andere mensen te laten zien, om heel te laten worden, zodat ook die mensen deel uit gaan maken van het gezin van God. Dat wil niet zeggen, dat wanneer iemand die niet heel is, een slachtoffer, geen deel uitmaakt van het gezin van God. Het slachtoffer staat als het ware met een been in het gezin. Ook wanneer het slachtoffer geen vertrouwen meer heeft in God en niet meer kan geloven, is er toch Gods ontferming en liefde voor het slachtoffer. Het is de taak van de discipelen om het slachtoffer heel te maken zodat ook zij ten volle deel kan uitmaken van het gezin van God.

Dit betekent dat wanneer het "wij" en "ons" als volgt geïdentificeerd worden: de opdracht in het gebed is niet gericht aan slachtoffers, of gemarginaliseerden. Het is gericht aan de discipelen. Het is een belangrijke opdracht, want Jezus herhaalt het direct na het gebed (Mt 6:14-15) en later nog een keer in hoofdstuk 18 van het evangelie. Hier wordt een gelijkenis verteld over een koning die een slaaf een onaflosbare schuld kwijtscheldt. De slaaf daarentegen handelt genadeloos tegen een andere slaaf die hem een veel kleiner bedrag schuldig is. Wanneer de koning dit hoort laat hij alsnog de eerste slaaf gevangen zetten om de schuld terug te betalen. Waetjen stelt de schuld van de eerste slaaf gelijk aan de schuld die de mens heeft ten opzichte van God, zijn Schepper die het onbetaalbare leven aan de mens en de mogelijkheden tot zelfrealisatie geschonken heeft. Dit roept verplichting op. Deze verplichting wordt in de joodse religie nog versterkt door de herinnering aan de bevrijding uit Egypte door God en het verbond wat gesloten is. Het boek Deuteronomium staat vol van deze ideologie en wederkerigheid. De koning in het verhaal echter bevrijdt de slaaf van zijn schuldlast die onmogelijk terug te betalen was en laat hem in vrijheid leven zonder verplichting. Dat is de genade van het nieuwe verbond. Is het echter wel een vrijheid van verplichtingen? Wanneer de slaaf weigert om zijn medeslaaf te vergeven, wordt de genade die hem geschonken is hem weer ontnomen. Hij wordt verplicht om anderen te vergeven.

Ook bij deze gelijkenis is heridentificering noodzakelijk. In de lijn van het Mattheüsevangelie is de eerste slaaf de vertegenwoordiging van de leiders van Israël, de Farizeeën. Zij hebben liefde en vergeving ontvangen, maar zij zien en horen het niet (Mt 13:10-15). Zij geven deze vergeving niet door aan de slachtoffers, de gemarginaliseerden, integendeel, zij veroordelen de slachtoffers. Wanneer de koning dit te horen krijgt, trekt hij zijn genade terug van de eerste slaaf. Dit wordt verderop in het evangelie zichtbaar wanneer Jezus zijn rede houdt tegen de schriftgeleerden en de Farizeeën. Deze rede is genadeloos (Mt 23). Hier komt Jezus op voor de slachtoffers van de samenleving. 
Een ander punt wat nog verdere toelichting vraagt, is de verandering van het woord "schuld" in het woord "zonde". Er bestaat een relatie tussen schuld en zonde. Dit wordt min of meer duidelijk in ieder rechtsysteem. Misdaad tegen iemand anders vraagt om compensatie en restitutie. Waetjen (1999:90-92) stelt de vraag wat vergeving doet in het rechtsysteem van het verbond in het Oude Testament, waar men uitgaat van: "oog om oog, tand om tand". Hij noemt dit een vicieuze cirkel, waarin een wraakzuchtige geest heerst. De vraag is of Waetjen hiermee de beschrijving in de Tora, het Oude Testament recht doet. In de wet en de profeten is het belangrijk dat er recht gedaan wordt. Dit heeft niet het karakter van wraak, maar is een vorm van restitutie, de benadeelde partij heeft recht op compensatie. Wanneer dit gebeurd is, wordt de zaak als gesloten beschouwd. Er is geen sprake van een vicieuze cirkel.

In het voorgaande zijn de verhoudingen tussen de verschillende karakters in het evangelie van Mattheüs aan bod gekomen. Daarmee is een nieuwe interpretatie van de voorwaarde voor goddelijke vergeving gegeven. Wat in deze nieuwe interpretatie nog ontbreekt is de weg van compensatie. Wanneer de discipelen het slachtoffer helpen om heel te worden, wil dit niet zeggen dat het slachtoffer niet om restitutie mag vragen. De jusitiële weg kan goed bijdragen aan de weg die het slachtoffer bewandelt om heel te worden. Er zijn twee verschillende niveau's aan te wijzen in het proces van heelwording. Het eerste niveau is het psychologische, aardse niveau. Daarin hoort ook de justitiële weg thuis. Dit is de weg van compensatie (propitiation) die ook terug te vinden is in de offertheologie. Het offer van Jezus was noodzakelijk om de toorn van God te stillen (Van Aarde 2002:518).

Het tweede niveau is dat van het geloof, de spiritualiteit. In dit niveau kan men de gedachtengang van Paulus plaatsen. Paulus gaat uit van vrijspraak (expiation) (Van Aarde 2002:518-519). Zo wordt de mens opnieuw verbonden met God. Dit is een ander soort vergeving, namelijk vergeving zonder dat de mens een compenserende bijdrage maakt. De "toorn van God" heeft plaatsgemaakt voor de "liefde van God".

Kortom het Mattheüsevangelie is een polemiek tussen Jezus en de Farizeeën. De Farizeeën worden geacht voor de verloren schapen te zorgen, de gemarginaliseerden, zoals Mattheüs hen karakteriseert. Zij hebben als het ware een positie tussen God en mens. De Farizeeën verzaken echter hun plicht. Zij zijn niet volmaakt, niet uit een stuk, ze handelen anders dan ze verkondigen. Ze leggen zoveel nadruk op het recht, dat er geen ruimte meer voor genade overblijft. De gemarginaliseerden zijn de slachtoffers van dit handelen en verkondigen. Jezus gaat tegen het beleid en verkondiging van de Farizeeën in, Hij komt op voor de slachtoffers en gemarginaliseerden van de 


\section{Ontferming "beyond" vergeving als weg naar heling en heelheid}

samenleving. De Farizeeën beseffen dat ze hun invloed dreigen kwijt te raken. Toch slagen ze erin om het volk achter zich te krijgen en zo Jezus te veroordelen en te laten kruisigen. De slachtoffers en gemarginaliseerden waar Jezus voor opkwam, schreeuwen dat Hij gekruisigd moet worden. Ze keren zich van Hem af. Jezus neemt het de mensen niet kwalijk, hij vergeeft de mensen bij voorbaat (LC 23:34). Hij stelt geen voorwaarde voor vergeving, maar betoont onvoorwaardelijke liefde. Dit is wat Jezus uit wil dragen: onvoorwaardelijke liefde. Door het uitdragen van deze liefde wordt het koninkrijk van God zichtbaar op aarde.

Volgens Ulrich Luz (1985:353) dienen de afsluitende verzen met de voorwaarde voor de goddelijke vergeving ervoor om de verbinding tussen bidden en handelen te verzekeren. Mattheüs wil duidelijk maken dat het gebed ook een stuk christelijke praxis is wat verderop in de Bergrede een vervolg krijgt (Mt 6:19-7:27). Het gebod om te vergeven ontspringt uit het gebod om lief te hebben, hetgeen volgens Luz het centrum is van de ethiek van Mattheüs (Luz 1985:353).

Deze liefde kan worden doorgegeven als slachtoffers heel geworden zijn. Zij kunnen dan op hun beurt meehelpen aan heling bij andere slachtoffers, want zij zijn dan leden geworden van het gezin van God. Wanneer dit gedaan wordt is er sprake van vergeving. De angel van het kwaad wordt uitgerukt. De dader staat in dit proces buiten spel. Vergeving bestaat daar uit dat het slachtoffer geen slachtoffer meer is. Zij is heel en kan vanuit die positie er zijn voor andere slachtoffers. Zij is vrij van de macht en van de neerdrukkende gevolgen van de macht die de dader over haar had.

\section{REFRAMING}

In de voorgaande hoofdstukken is de noodzaak duidelijk geworden van "gezonde" theologische denkbeelden en om "beyond" het verhaal van het slachtoffer te komen. Alleen dan kan er reframing plaatsvinden. Reframing wordt vervolgens uitgewerkt met als leidraad het werk van Donald Capps (1990). Hij beschrijft aan de hand van case-studies hoe reframing werkt en wat het vereist van de pastor (Capps 1990:3). Ten eerste wordt er een overzicht gegeven van de denkbeelden van Capps. Vervolgens wordt de theorie van Capps toegepast op dit onderzoek.

\subsection{Reframing volgens Donald Capps}

Capps maakt gebruik van de onderscheid die Watzlawick, Weakland en Fisch (1974) in hun boek, Change: Principles of problem formation and problem resolution, maken tussen de "first order change" en de "second order change". De eerste orde verandering komt voor in een systeem wat in zichzelf 
onveranderd blijt. De tweede orde verandering is de verandering van het systeem zelf. Hij noemt als voorbeeld een persoon die een nachtmerrie heeft. In een nachtmerrie kan een persoon op verschillende manieren handelen. Hij of zij kan vluchten, vechten of zich verbergen. De situatie zelf echter verandert niet. Een verandering op dit niveau is een eerste orde verandering. De tweede orde verandering vindt plaats wanneer de persoon ontwaakt. Er is een geheel andere situatie ontstaan. Wakker zijn maakt geen deel uit van de droom. De persoon is in een hele andere toestand. Het is een verandering in zichzelf. In een eerste orde verandering kan een persoon heel veel veranderen, maar de situatie blijft min of meer hetzelfde. In de tweede orde verandering is alles anders omdat het systeem in zichzelf niet langer hetzelfde is. Het is een verandering van de verandering. De praktische manifestatie van de tweede orde verandering is vaak onlogisch en paradoxaal, zoals een commandant van een kasteel die zijn voedsel weggooit om te overleven (zie Watzlawick et al 1974:10-12).

Met dit onderscheid tussen de eerste en tweede orde verandering legt Capps (1990) drie manieren uit waarop moeilijkheden worden benaderd - drie schadelijke manieren. De eerste manier is simplificatie. Dit is onder te verdelen in twee vormen. De eerste vorm is ontkenning van de moeilijkheid. Dit gaat vaak gepaard met een aanval op mensen die het er niet mee eens zijn en vinden dat er actie moet worden ondernomen. De tweede vorm van simplificatie is door te erkennen dat er een kleine moeilijkheid is, maar erop aandringen dat de moeilijkheid bezworen kan worden met een eenvoudige oplossing.

De tweede manier waarop moeilijkheden verkeerd benaderd worden, is utopianisme. Hier wordt gepoogd een moeilijkheid te veranderen die niet bestaat of die niet te veranderen valt. Deze benadering is net als voorgaande ook onder te verdelen in twee vormen. De eerste vorm is introjectief utopianisme. Dat wil zeggen dat een persoon diepe pijnlijke gevoelens heeft over zijn of haar eigen tekortkomingen. Deze persoon probeert doelen te bereiken die onbereikbaar zijn. De symptomen van deze vorm van utopianisme zijn onder andere: depressiviteit, nihilistisch wereldbeeld, vervreemding en gedachten over zelfmoord. De tweede vorm is projectief utopianisme. Het belangrijkste ingrediënt van deze visie is een houding gebasseerd op de overtuiging dat de waarheid gevonden is. Dit wordt ondersteund door een missionaire verantwoordelijkheid om de wereld te veranderen. Hier ligt het probleem niet in het feit dat de doelen die gesteld worden onhaalbaar zijn, maar aan de omgeving die verschilt van de visie. De symptomen van deze vorm van utopianisme zijn onder andere: paranoïde, 


\section{Ontferming "beyond" vergeving als weg naar heling en heelheid}

zelf-rechtvaardiging en de illusie van originaliteit. ${ }^{4}$ Het idee dat men de oplossing heeft voor de moeilijkheden van de wereld die eigenlijk onoplosbaar zijn, rechtvaardigt een vijandige houding ten opzichte van anderen. De illusie bestaat dat de oplossing nieuw is en dat iets dergelijks nog nooit geprobeerd is. Deze twee vormen van utopianisme zijn in een opzicht te vergelijken: het idee dat een perfect geluk bereikt kan worden of dat het onoplosbare opgelost kan worden, terwijl de ervaring heeft bewezen dat deze doelen onbereikbaar zijn.

De derde manier waarop moeilijkheden verkeerd benaderd worden, is de paradox. Er wordt actie ondernomen op het verkeerde niveau. Men probeert een eerste orde verandering tot stand te brengen waar de tweede orde verandering noodzakelijk is en andersom. ${ }^{5}$ Wanneer men een eerste orde verandering probeert waar een tweede orde verandering noodzakelijk is, worden mensen gevangen gezet in de eerste orde verandering. Pas wanneer men ziet wat de gepoogde oplossingen eigenlijk zijn, namelijk een paradox, ontstaat er ruimte voor de tweede orde verandering (vgl Watzlawick et al 1974:31-61).

Deze theorie wordt vervolgens toegepast op de narratieve theorie van Christie Neuger (2001; zie Van der Schaaf \& Dreyer 2004) ten opzichte van counselen met vrouwen en het werk van T W Buckley over vergeving in Matteüs. Daar wordt duidelijk waar het probleem zit in Buckley's interpretatie van het evangelie volgens Matteüs.

\subsection{Neuger en Buckley vanuit het gezichtspunt van Capps}

Het is bij Neuger (2001) niet duidelijk op welk niveau de veranderingen plaatsvinden. Wanneer zij Ballou \& Gabalac (1985) aanhaalt, beschrijft ze een complexe leefsituatie van vrouwen. Het gaat hier voor vrouwen over "ik-benmet-anderen". De situatie moet in zichzelf veranderen. Neuger maakt het onderscheid in niveau van verandering niet, terwijl juist de narratieve methode dit onderscheid wel in zich heeft. De narratieve methode gaat immers uit van de sociaal-constructionistische metafoor. Dat wil zeggen dat er juist rekening wordt gehouden met de invloeden die de sociale realiteit heeft op het leven van mensen. De manier waarop Neuger de theologie gebruikt in haar counseling, maakt verheldering van deze counselingmethode noodzakelijk.

De uitleg van het evangelie van Matteüs die Buckley slachtoffers van seksueel geweld oplegt, is een van de schadelijke manieren om moeilijkheden

\footnotetext{
${ }^{4}$ Een voorbeeld hiervan is het koninkrijk als "hiernamaals-idee" van Buckley. Hij verplaatst het gericht buiten de tijd van de menselijke, aardse ervaring.

${ }^{5}$ De verplaatsing van de offertheologie van "propitiation" (justitiële weg) naar "expiation" (vergeving van zonden) is een voorbeeld van de paradox.
} 
te lijf te gaan. Wat Buckley doet, is projectief utopianisme. Het belangrijkste ingrediënt van deze visie is een morele, gerechtvaardigde houding die gebasseerd is op de overtuiging dat de waarheid gevonden is. Mensen met deze visie denken dat ze een originele oplossing hebben voor de moeilijkheden van deze wereld die onoplosbaar zijn. De uitleg die Buckley geeft, komt voort uit een apocalyptische radeloosheid. Dat wil zeggen dat er bepaalde voorwaarden zijn waaraan mensen moeten voldoen om toegang te krijgen tot het koninkrijk van God. Voor slachtoffers wordt het extra moeilijk. Zij zijn slachtoffer gemaakt. Nu krijgen ze daarnaast de opdracht om de dader te vergeven, want dat is de voorwaarde voor de toegang tot het koninkrijk en voor Gods vergeving. De "oplossing" die Buckley geeft voor dit probleem, is de kruisdood van Jezus. Door zijn dood aan het kruis worden de zonden van mensen vergeven.

Naast het projectief utopianisme staat in dit geval de paradox. Met deze "oplossing" worden de problemen van het slachtoffer nog groter. Buckley past hier een eerste orde verandering toe, waar een tweede orde verandering noodzakelijk is. Hij brengt een verandering aan op het verkeerde niveau. Het gevolg daarvan is dat er uiteindelijk helemaal geen verandering optreedt. De situatie in zichzelf blijft hetzelfde. Het slachtoffer blijft in een vicieuze cirkel zitten waar zij niet uit kan komen, zolang de verbindingen tussen God, geweldenaar en slachtoffer op deze manier gehandhaafd blijven.

\subsection{Reframing, configuratie en refiguratie}

Zoals in de voorgaande paragraaf reeds genoemd werd, is hier een tweede orde noodzakelijk. De situatie in zichzelf moet veranderen. Dit wordt duidelijk in de theorie van Marten Heidegger (1962:42, 44; vgl Inwood 2000:20-30; Collins \& Selina [1999] 2001:63). Hij maakt een onderscheid tussen "Sein" (ik ben) en "Dasein" (mijn existentie). Een mens is niet alleen een "ik-ben" (Sein), maar ook een "ik-ben-met-anderen" (Dasein). Een verandering op het niveau van de eerste orde verandering vindt plaats in het "ik-ben". Dit is niet daadwerkelijk een verandering. Dit komt er voor het slachtoffer op neer dat ze moet adapteren, zich moet aanpassen aan de situatie, die daardoor onveranderd blijft. Dit kan ongezond zijn. De verandering die noodzakelijk is voor het slachtoffer, vindt plaats op het niveau van "ik-ben-met-anderen", een tweede orde verandering.

De vraag is hoe dat tot stand kan worden gebracht. In het voorgaande is een alternatieve interpretatie van het evangelie volgens Mattheüs gegeven. Door het heridentificeren van bepaalde karakters onstaat er een heel ander beeld van de situatie. De situatie zelf wordt anders. In de eerste plaats is er de verandering van identificatie wat betreft het woordje "ons" in het Onze 


\section{Ontferming "beyond" vergeving als weg naar heling en heelheid}

Vader. Daarmee werden de discipelen aangeduid. Zij zijn degenen die het gebed van Jezus leren, nadat zij heel geworden en vergeven zijn. Zij krijgen nu de opdracht om deze ervaring door te geven aan andere mensen. Met deze interpretatie wordt de druk van het slachtoffer weggenomen. Zij is nog niet heel. Haar verhaal moet nog verteld worden.

Ook de herinterpretering van de karakters in de gelijkenis van Matteüs 18 geeft een andere kijk op de zaak. De vrouw die tot slachtoffer gemaakt werd mag niet geïdentificeerd worden met de eerste slaaf. Zij maakt deel uit van de gemarginaliseerden, de slachtoffers van de maatschappij. Haar wordt juist geweld aangedaan door de eerste slaaf, de geweldenaar. Deze herinterpretering betekent bevrijding voor het slachtoffer. Zij wordt niet buitengesloten omdat zij niet kan vergeven of omdat zij niet meer kan geloven. Integendeel, zij valt binnen Gods barmhartigheid. Het is juist de schare, de gemarginaliseerde aan wie gerechtigheid gedaan moet worden (Ex 22:21-24; Zc 7:9-10). Jezus leeft deze boodschap voor, laat het de discipelen ervaren en onderwijst hen hoe zij dit andere mensen (de gemarginaliseerden, de slachtoffers) kan laten ervaren. Het is de opdracht van diegenen die al heel zijn, die al vergeving hebben ontvangen om voor deze slachtoffers te zorgen, zodat ook zij heel kunnen worden. Het slachtoffer komt zo niet alleen in een andere verhouding tot God te staan, maar ook in een andere verhouding tot de geweldenaar. Wat van belang is, is dat het slachtoffer heel wordt. Waneer het slachtoffer heel is, uit een stuk bestaat, dan zal zij beseffen dat ook zij dit door kan en moet geven aan andere slachtoffers om hen te helpen heel te worden. Nu zij heel is geworden, betekent dit dat zij vrij is. Zij is vrijgesproken (expiation). Zij is deel geworden van de huishouding van God en kan zo ook andere gemarginaliseerden en slachtoffers helpen om heel te worden. Er is geen verbinding met de geweldenaar meer. Vergeving bestaat daaruit dat het ex-slachtoffer andere slachtoffers helpt om heel te worden. Op dit manier draagt ze de vergeving en genade van God uit. De geweldenaar komt op deze manier buiten spel te staan. De angel van het kwaad wordt uitgerukt. Het slachtoffer is vrij van de neerdrukkende gevolgen van de macht die de geweldenaar over haar had. Dit is een tweede orde verandering, de situatie is in zichzelf veranderd.

Deze verandering van de situatie in zichzelf, de tweede orde verandering, is de configuratie in het model van Ricoeur. Met deze interpretatie van het Mattheüsevangelie gaat men "beyond" de offertheologie. Het verhaal van het slachtoffer wordt herschreven en krijgt een hele andere wending. In deze configuratie komen de psychologie en de theologie bij elkaar. Het zijn verschillende niveau's die allemaal bijdragen tot de tweede orde verandering. Het eerste niveau is het aardse niveau, de verhouding met 
andere mensen, het volgen van de justitiële weg, de weg van compensatie (propitiation), de weg van de psychologie. Daarnaast is er een hoger niveau: "beyond" het niveau van de justitiële, oordelende offertheologie, is er het niveau van het geloof, de spiritualiteit, de bevrijding. Deze twee niveau's komen samen in de configuratie, zodat er een refiguratie kan plaatsvinden, een tweede orde verandering, een verandering van de verandering.

In het Mattheüsevangelie wordt de "refiguratie", de reframing gedemonstreerd in de opdracht die de discipelen krijgen om niet het brood van de Farizeeën (Mt 16:9-12) aan de gemarginaliseerde schare (Mt 14:19b; 15:36b) te geven, maar het brood van Jezus. Bij Paulus wordt het "apocalyptische oordeel" van de Judeeërs (1 Ts 2:14-16) vervangen door een gebed dat Israël de gerechtigheid van God zal inzien en Gods vrijspraak zal ontvangen (Rm 10:1-4). Paulus belichaamt deze paradox persoonlijk. Hij doet de "reframing" (refiguratie) zelf voor de slachtoffers van de "leiders van Israël", de armen van Judea, door geld in te zamelen voor de armen. Hierdoor verandert zijn persoonlijke situatie, ook al blijft hij nog steeds een verworpene. Paulus is geen slachtoffer meer van de neerdrukkende gevolgen van de macht van zijn geweldenaars (Rm 15:15-27, 30-33.

\section{BEVINDING GEREALISEERD}

Uit het voorgaande is het duidelijk geworden dat er twee niveau's zijn waarop heling van het slachtoffer kan plaats vinden. Het eerste is dat van het aardse niveau, de justitiële weg, de weg van genoegdoening. Het tweede niveau is dat van het geloof, de spiritualiteit, de vrijspraak. Het slachtoffer wordt vrijgesproken van de neerdrukkende macht die de geweldenaar over haar heeft. De relatie tussen geweldenaar/slachtoffer en slachoffer God verandert. $\mathrm{Er}$ is niet meer een directe verbinding tussen geweldenaar en slachtoffer. De vergeving van het slachtoffer bestaat uit het heelworden. Wanneer zij heelwordt kan zij verder leven en andere slachtoffers helpen met heel worden. Hiermee wordt het kwaad verder bestreden en de geweldenaar buiten spel gezet. De pastors hebben hierin een belangrijke rol. Zij gaan met het slachtoffer op zoek naar achter ("beyond") het verhaal zelf. Wanneer dit niet gebeurt, is het verhaal verloren en blijven pastor en slachtoffer op het niveau van een eerste orde verandering. Wanneer pastor en slachtoffer wel in staat zijn om "beyond" het verhaal te komen kan de tweede orde verandering plaatsvinden en zal de situatie waarin het slachtoffer zich bevindt in zichzelf veranderen. Dan wordt een heel leven mogelijk, het slachtoffer is geen slachtoffer meer, zij bestaat uit één stuk. Zij is volmaakt, gelijk haar hemelse Vader volmaakt is (Mt 5:48). Zij zijn vergeven, want zij zijn heel gemaakt. Nu kunnen ze andere slachtoffers vergeven door hen te helpen, heel te worden. 
Ontferming "beyond" vergeving als weg naar heling en heelheid

\section{Lijst van aangehaalde werken}

Ballou, M \& Gabalac, N W 1985. A feminist position on mental health. Springfield, II: Charles C Thomas.

Buckley, T W 1991. Seventy times seven: Sin, judgement, and forgiveness in Matthew. Collegeville, MN: The Liturgical Press.

Capps, D 1990. Reframing: A new method in pastoral care. Minneapolis, MN: Fortress.

Collins, J \& Selina, H [1999] 2001. Introducing Heidegger. Cambridge: Icon Books. Derrida, J 1978. Writing and difference, vertaald door A Bass. Londen: Routledge.

Duyndam, J \& Poorthuis, M 2003. Kopstukken filosofie: Levinas. Amersfoort: Lemniscaat.

Ganzevoort, R R \& Veerman, A L 1999. Geschonden lichaam: Pastorale gids voor gemeenten die geconfronteerd worden met seksueel geweld. Zoetermeer: Boekencentrum.

Heidegger, M 1962. Being and time, vertaald door J Macquarrie en E Robinson, Oxford: Oxford University Press.

Inwood, M 2000. Heidegger: A very short introduction. Oxford: Oxford University Press.

Lachs, S T 1987. A rabbinic comentary on the New Testament. New Jersey: Hoboken KTAV.

Luz, U 1985. Matthäus, I. Zürich: Benziger Verlag. (EKK 1.)

Minear, P S 1982. Matthew: The teacher's gospel. New York: The Pilgrim Press.

Neuger, C C 2001. Counseling women: A narrative pastoral approach. Minneapolis, MN: Fortress.

Van Aarde, A G 1994. God-with-us: The dominant perspective in Matthew's story, and other essays. Pretoria: Gutenberg Publishers.

Van Aarde, A G 2002. Die "evangelie" van Paulus. Verbum et Ecclesia 23(2), 516532.

Van Aarde, A G 2003. Die ou-Kersaandgesprek van Friedrich Schleiermacher in Afrikaans: Agtergrond, vertaling en hermeneutiek. HTS 59(2), 545-568.

Van der Schaaf, T S \& Deyer, Y 2004. Ontferming "beyond" vergeving als weg naar heling en heelheid: "Reframing" als narratief-pastorale bemachtiging. HTS 60(3), 1127-1147.

Waetjen, H C 1999. Praying the Lord's Prayer: An ageless prayer for today. Harrisburg, PA: Trinity Press International.

Watzlawick, P, Weakland, J \& Fisch, R 1974. Change: Principles of problem formation and problem resolution. New York:Norton. 